calculate the Fourier coefficients and display the reconstructed outlines.

The hyriid mussel Alathyria jacksoni has either a curved anterior-posterior ridge (arched) or a straight ridge (winged), depending upon environmental factors. Using the Fourier coefficients I calculated a discriminant function which distinguished perfectly between the two growth forms (see figure). I was surprised by this outcome as to distinguish the two forms by eye requires more information than just the valve outline; the posterior ridge and muscle scars must also be examined. The mussels could be separated into winged and arched groups by principal components analysis.

Department of Zoology, University of Adelaide, GPO Box 498. Adelaide. South Australia 5001, Australia

1. Klaczko, L.B. \& Bitner-Mathe, B.C. Nature 346, 321 (1990)

2. Kaesler, R.L. \& Waters, J.A. Geol. Soc. Am. Bull. 83 , 1169-1178, (1972)

3. Kuhl, F. \& Giardina, C.R. Comput. Graphics Image Process. 18, 236-258 (1982).

\section{Hot springs and the origin of life}

SiR-Miller and Bada' argue that prebiotic synthesis leading to the emergence of life could not have occurred in submarine hot springs. They state that "there is no thermal gradient until the waters at $\sim 350{ }^{\circ} \mathrm{C}$ exit the vents and are rapidly quenched to deep ocean temperatures. Thus, the only thermal gradient in the system is in the area near the vent opening, which is where the proposed organic synthesis and further steps in the origin of life would have to take place."

This description of the nature of submarine hot springs is incorrect. In addition to the high-temperature vents they describe, there are the ubiquitous lowtemperature vents resulting from a distinct fluid trajectory (see figure). Hotspring fluid samples collected on the Galapagos Rift in 1977 (ref. 2) revealed that the low-temperature vent fluids are produced by mixing within the crust of a high-temperature component, which last equilibrated with the rock at $350{ }^{\circ} \mathrm{C}$, and ambient sea water which saturates the surrounding fractured crust. These Galapagos-type vents always accompany hightemperature smoker vents ${ }^{3}$.

Miller and Bada cite the suggestion of Turekian and Cochran ${ }^{+}$, based on radionuclides in clams from the vents, that the fluids remain within the crust at extreme temperatures for tens of years. Two findings refute this.

First, retaining large volumes of hightemperature fluids ${ }^{5}$ within the crust is problematic. Thermal budgets of submarine hot springs show that heat is extracted from the magma by the advance of a cracking front' into the magma body (see figure). Carbon in the magma and the seawater equilibrate isotopically ${ }^{8}$ at 640 to $720^{\circ} \mathrm{C}$ in the chemical environment produced by the reaction of superheated water with the hot rock. Buoyant forces acting on these supercritical lowdensity/low-viscosity fluids inevitably lead to their rapid ascent, and to rapid mixing and quenching of hot fluid with cold sea

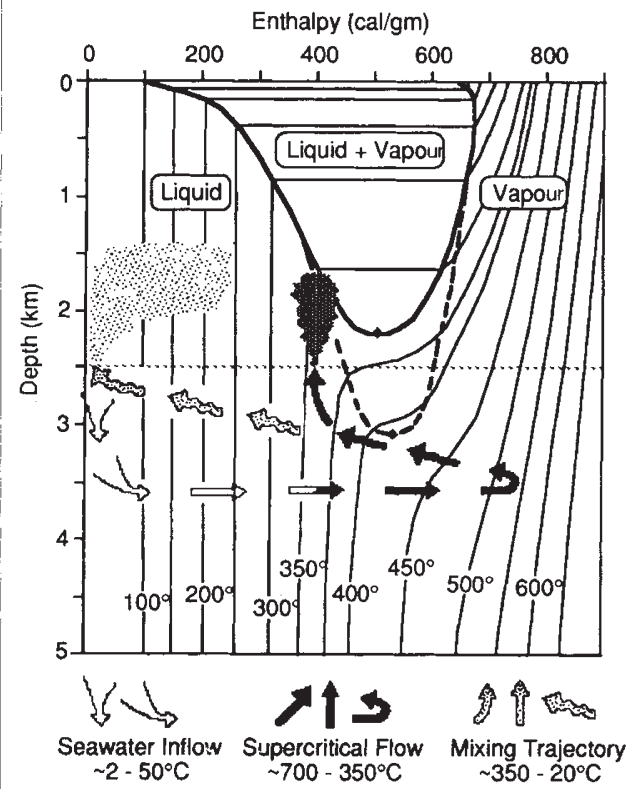

Concentrations of biologically produced organic compounds would mask any abiogenic component.

Joyce's News and Views comment ${ }^{11}$ on Miller and Bada's paper, that "it is almost inconceivable" that the first living system was not a heterotroph, overlooks evidence from analysis of nucleotide sequences in $16 \mathrm{~S}$ ribosomal RNA in modern organisms, which strongly suggests that a chemosynthetic thermophile

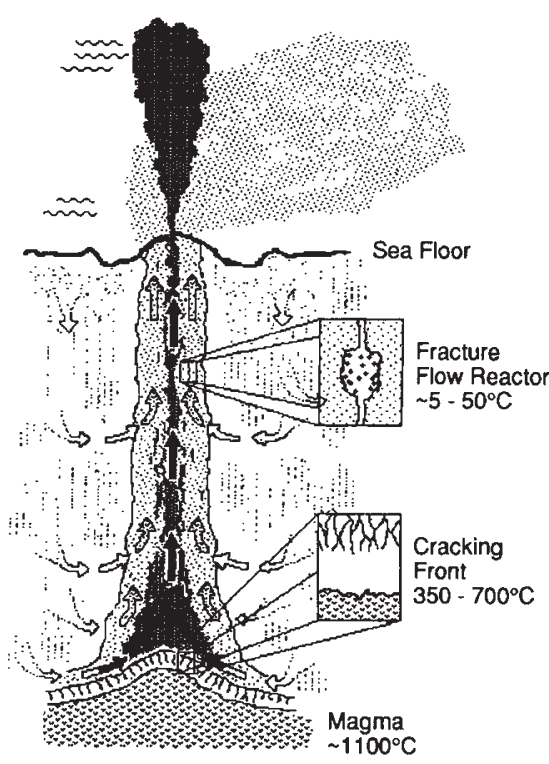

Fluid trajectoi ies in submarine hot springs. The data are for fresh water with the critical point of sea water drawn in; $2,500 \mathrm{~m}$ is a typical sea-floor depth for mid-ocean ridge hot springs. A typical trajectory into the system, and two alternative pathways out, is shown on the enthalpy-depth diagram. The hot-spring model proposes that a fraction of the supercritical fluid produced at low temperature, by contrast to the fraction which rises rapidly without mixing to emerge as the "smoker" vents referred to by Miller and Bada. (From ref. 14)

water drawn in from the surrounding permeable crust.

Second, Kadko and Moore conclude from extensive radionuclide data on actual hot-spring fluid samples that the residence time of the fluids is much shorter. Their data are compatible with rapid heating and quenching.

The presence of the mixing trajectory in the hot springs obviates the objections of Miller and Bada. Rapid quenching allows the conversion of thermal energy into high-energy bonds of the appropriate molecules which survive at low temperatures, lower than $50^{\circ} \mathrm{C}$ for example.

Miller and Bada's claim that polymerization of amino acids into polypeptides will not occur in the presence of liquid water is contradicted by the work of Yanagawa and colleagues ${ }^{10}$, who report the production of polymers with peptide bonds in a modified sea water containing amino acids held at hot-spring temperatures for several weeks.

Miller and Bada's proposed analysis of the vent fluids searching for abiotically synthesized organic molecules would probably be futile in the relevant low temperature vents. These fluids contain up to $10^{8}-10^{\prime \prime}$ bacteria per $\mathrm{cm}^{3}$ (ref. 2). was the closest descendant of the earliest self-replicators ${ }^{12}$. An enormous standing crop of these bacteria live within fracture "flow-reactors" in the warm upper reaches of these convective systems today. These natural analogues of Eigen's evolution reactor ${ }^{13}$ provide an optimum site for the emergence of these chemosynthetic thermophiles from non-living systems ${ }^{i 4}$.

JOHN B. CORLISS

Computer Systems Research Facility: Code 935 ,

NASA Goddard Space Flight Center, Greenbelt, Maryland 20771, USA

1. Miller, S. L. \& Bada, J. L. Nature 334, 609-611 (1988)

2. Corliss, J. B. et al. Science 203, 1073 (1979)

3. Spiess, F. N. et al. Science 207, 1421-1433 (1980).

4. Turekian, K. K. \& Cochran, J. K. Proc. natn. Acad Sci. U.S.A. 83, 6241-6244 (1986)

5. Macdonald, K. C. Earth planet. Sci. Lett. 48, 1-7 (1980).

6. Cann, J. R. \& Strens, M. R. Nature 298, 147-149 (1982)

7. Lister, C. R. B. Geophys. J. R. astr. Soc. 39, 465 (1974).

8. Welhan, J. A. \& Craig, $\mathrm{H}$. in Hydrothermal Processes at Sea Floor Spreading Centers (eds Rona, P. A. et al.) (Plenum, New York, 1983).

. Kadko, D. \& Moore, W. Geochim. cosmochim. Acta $\mathbf{5 2}$ $659-668(1988)$

10. Yanagawa, $\mathrm{H}$. et al. Origins Life Evol. Biosph. 18, 179207 (1988)

11. Joyce, G. Nature 334, 564 (1988)

12. Woese, C. R. Microbiol. Rev. 51, 221-271 (1987)

13. Eigen, M. Naturwissensdusen 58, 465-523 (1971).

14. Corliss, J. B. Life is a Strange Attractor (Aeriel, Santa Cruz, in the press) 